\title{
Birthplace of a nation? Why Sydney voted no to Federation
}

\author{
Zachary Gorman ${ }^{1}$
}

\section{Abstract}

While most colonies delivered overwhelming 'Yes' majorities in the referendums of 1898-1900, New South Wales twice delivered sizeable 'No' minorities. On both occasions the 'No' vote centred around the free trade stronghold of Sydney, which determined that she did not want to sacrifice her independence. Up until now this remarkable rejection has received little academic attention This article argues the main reason why Sydney voted against Federation was because it cut against the main political development of the preceding years-namely Reid's successful electoral program, which championed free trade, democracy and domestic reform.

\section{Introduction}

The referendums of 1898-1900 saw the voters of the six Australian colonies express their democratic will in favour of the Federal Constitution that had emerged first from the Federal Conventions and then from the 'secret' Premiers' Conference. While most colonies delivered overwhelming 'Yes' majorities, New South Wales twice delivered sizeable 'No' minorities that demonstrated severe doubts and trepidations in the 'Mother Colony'. On both occasions, the 'No' vote centred around the free trade stronghold of Sydney, as Australia's oldest city, and the capital of what had recently re-emerged as the largest colony, had determined that she did

1 The Institute of Public Affairs, zgorman@ipa.org.au. 
not want to sacrifice her independence along the proposed lines. ${ }^{2} \mathrm{Up}$ until now, this remarkable fact has received little academic attention, particularly when it comes to the otherwise successful referendum of 1899 . Despite this neglect, the doubts expressed by Sydney are of great historical importance. As the 'No' campaign's greatest victory, the Sydney vote demonstrates the strength of the opposition to Federation and that its accomplishment was by no means inevitable. This piece will argue that one of the main reasons why Sydney voted against Federation was because in its details it cut against the main political development of the preceding years-namely George Reid's successful electoral program, which championed free trade, democracy and domestic reform. Reid was one of the main drivers behind the accomplishment of Federation, but its success left a significant dent in his political legacy by helping to undermine the New South Wales tariff policy and increasing the overall cost of government.

It is relatively easy to understand why few people have decided to examine the Sydney vote in detail. History is written by the victors and it is difficult to drum up interest in a 'lost cause'. This was demonstrated by the participants themselves. While 'Yes' campaigner Bernhard Wise (1913) wrote a gloating account of Federation's victory in the face of Reid's supposed treachery, 'No' supporters like Attorney-General Jack Want and prominent Legislative Councillor Dr Normand MacLaurin 'licked their wounds in silence' (Crisp, 1990). By continuing this trend, academics risk turning Australian history into a teleology that guides events along a set track. The choice of whether to federate was by no means simple. To New South Wales, the proposal to give up a great deal of sovereignty and place decisions in the hands of representatives of other states, who would be vastly overrepresented in the Senate and even to some degree in the House of Representatives, was no small ask. The purpose of this article is to resurrect and treat as legitimate the arguments of the 'No' case. Even someone who holds the traditional positive view of Federation diminishes the practical achievement if they disregard its opponents.

One of the more comprehensive accounts of the referendum campaigns in New South Wales has long been that provided by Quick and Garran in their Annotated Constitution of the Australian Commonwealth (1901). While this benefits from an eyewitness view, the authors are perhaps too close to their subject, with Robert Garran having been an active participant in the 'Yes' campaign and who wrote an explanation of the constitution that was mailed to every elector before the 1898 poll. John La Nauze (1972) declared that a detailed study of the referendum campaigns was sorely needed, but he did not find the time nor space in The Making of the Australian Constitution. More recently, John Hirst (2000) and Helen Irving (1999) have incorporated accounts of the referendums in their Federation works, but both are brief and to some extent coloured by their knowledge of the result. Irving is

2 This article uses the 11 city and 28 suburban seats identified by the Sydney Morning Herald (SMH), 4 June 1898 , to define 'Sydney' as an electoral entity. 
particularly dismissive of the 'No' case, beginning her analysis of the 1898 result by saying 'the Yes vote was, of course, higher than the No vote' (1999, p. 79). Rosemary Pringle (1979) filled some of the gap identified by La Nauze through her examination of 'Public Opinion in the Federal Referendum Campaigns in New South Wales 1898-99'. This provides a critical analysis of the forces arranged on both the 'Yes' and the 'No' sides, and correctly identifies that the referendums were fought primarily on the terms of the draft constitution bill rather than on Federation as an abstract concept. While admirable, Pringle's work has some significant limitations when it comes to understanding both the 'No' case and why it resonated in Sydney. It only engages with the 'No' arguments in a summarised manner and it treats Federation as a separate political issue rather than placing it in its domestic political context. Even 'The Federation Issue in New South Wales Politics 1891-99', also written by Pringle (1975), is too Federation-centric to overcome the latter issue.

Other than Pringle, accounts that treat the 'No' campaign with any sympathy or depth have tended to come from those approaching the question from the perspective of George Reid or the Labor Party. W.G. McMinn (1989) and L.F. Crisp (1990) have both complimented Reid's constructive criticism of the 1898 draft, while failing to see much merit in those who thought that the amendments he secured before the 1899 poll were inadequate. Similarly, Bede Nairn (1973) has shone a light on the significant efforts of Labor men to secure a more democratic Federation. Nairn even hints at what is a central argument of this piece, namely that the reason Federation was so controversial in Sydney's political climate was that it struck against the central characteristics of the popular and reforming Reid government. As he puts it, Reid 'had done so much to help create the conditions that shaped all these [negative] opinions' of the Federation bill (1973, p. 178).

The driving principles of the Reid government were democracy in putting the burdens of taxation on the rich and fighting the nominee Upper House, free trade economics that drove tariff reform and Reid's entire platform, and the rationalisation of government through budget reform and the creation of the Public Service Board (McMinn, 1989). The constitution bill threatened to undermine democracy through the Senate, force high tariffs through the 'Braddon blot' and create an irrational government with overlapping responsibilities and unnecessarily high taxation. From a New South Wales perspective at least, few of the supposed practical benefits of Federation could stand up to close scrutiny of the details of how it would work. Instead, the 'Yes' campaign had to rely on appeals to emotion, the 'crimson thread of kinship' or 'one people, one destiny'. That they succeeded in creating a climate where even opponents of the bill had to insist that they supported Federation in principle speaks to the overwhelming influence of nationalism in late nineteenthcentury Australia (Hirst, 2000). The fledgling nation was caught up in an ideology that was sweeping much of the world (Kemp, 2019). 


\section{Background}

While it is unnecessary to give a complete recap of the history of Federation leading up to the referendums, it is important to draw out a few points about how the issue had developed in New South Wales. The simplest but most important thing to reiterate is that New South Wales had a successful constitution, healthy democracy, growing population, fertile lands, rich resources and a resilient economy. The $1890 \mathrm{~s}$ were a time of economic depression, but both the official statistics and popular perception suggested that the colony was in a better position than Victoria, whose protectionist policies had seen a reduction in population growth and aggregate trade even before the crash (Coghlan, 1898). In an alternate timeline the colony could and would have grown into a distinct country in and of itself. There was no clear necessity to federate. The electors enjoyed universal manhood suffrage and the secret ballot, and were used to voting on the future direction of their community. They would have to be convinced that enlarging that community was worthwhile and that by doing so they would not lose control over it.

While leading men like Wentworth had often speculated on the idea, New South Wales had shown itself to be somewhat reluctant to cooperate with her fellow colonies on equal terms (Persse, 1967). The Mother Colony had, after all, controlled at one point all of Eastern Australia, and areas like the Port Phillip district had essentially scorned her in asking for their independence. Joseph Carruthers reflected a common snobbery when he described Federation as an effort to gather up the 'wandering brood that once owed allegiance to and formed part of the colony' (Gorman, 2018, p. 143). Pringle identified a sentimental and economic New South Wales 'nationalism' that was able to cut across Federation's more blatant appeal to patriotic emotion. She dubbed New South Wales 'the most self-conscious of the colonies', and this was certainly reflected in Parkes' infamous plan to rename his colony 'Australia' (Pringle, 1979, pp. 244-245).

This tendency was severely exacerbated by the fiscal issue. When Victoria erected great tariff barriers against the trade of her neighbours, most of whom retaliated in kind, New South Wales had taken what many saw as a principled stand by upholding comparatively free trade. This was both an economic and ideological policy, inspired by celebrated British politicians like Cobden and Bright, which was sold to the working class as something that reduced the price of necessities like tea and sugar (Kemp, 2019). Though its supporters tried to portray free trade as an antiparochial stance, New South Wales was not innocent of manipulating the market against her sisters. Geographical reality meant that perhaps no city benefited more from arbitrary colonial boundaries than Sydney. Without these barriers, the farmers and graziers of the Riverina would export their product via Melbourne, Broken Hill's mineral wealth might have ended up in Adelaide, and the Northern Districts' sugar plantations would have been marketing in Brisbane (Quick \& Garran, 1901). 
The Protectionist members of the New South Wales Parliament were predominantly from the country districts where farmers wanted protection from intercolonial competition and landowners were wary of a land tax.

Thanks in part to its economic importance in a mercantile port city, free trade became a defining part of New South Wales and particularly Sydney's identity. The only elections where the Protectionists secured the largest number of seats were 1891 and 1898, when Federation obscured the fiscal issue, and even then the Free Trade governments survived until Labor voted against them. The centrality of the fiscal issue to Federation was clearly demonstrated when Henry Parkes, the self-styled champion of free trade, stood aloof from the formative Federal Council to protest the tariff policy of its other members.

Ironically it was Parkes who resurrected the Federation issue as a way of distracting a Free Trade Party that had grown frustrated that he would not introduce an ideologically pure free trade tariff. After Parkes delivered his famous Tenterfield speech, much of his cabinet protested that the Premier had failed to consult them beforehand (Martin, 1980). When the National Australasian Convention produced a draft constitution, it was the independent Free Trader George Reid who led the opposition to it. He produced blistering criticisms claiming that the bill threatened free trade, gave an undemocratic Senate too much power over money bills and failed to proscribe a clear model of responsible government (McMinn, 1989). This brought the Federation movement to a standstill, and when Reid soon replaced Parkes as leader of the Free Trade Party, this reflected a choice to prioritise domestic reform over nationalistic visions (Gorman, 2016).

Reid won the 1894 election with a promise to take the burden of what was a relatively small government off the backs of the masses and onto those with significant land and income. McMinn (1989) argues that the direct taxes appealed to the working class and radicals, without alienating a middle-class base that accepted that they were necessary for true free trade to be implemented. The nominee Upper House tried to block his main reforms, teaching Reid through experience that a powerful and obstructionist second chamber could create a constitutional crisis. To force the Legislative Council's hand, Reid called a snap election for 1895 that produced a campaign replete with democratic rhetoric and a virtual Free Trade-Labor alliance. ${ }^{3}$ The result saw Free Trade, Labor and independent Free Trade win all but three of Sydney's 39 seats, a stunning endorsement of the Reidite program (Green, 2007). Of the three seats the Protectionists did win, two were helped by a split vote among their opponents.

3 Free Traders did not contest Labor seats and Labor partially returned the favour (Nairn, 1973). 
The government was able to reduce New South Wales' tariff schedule to one of the shortest in the world and improve public service efficiency, while a strong recovery from the 1890s depression seemed to prove the economic case for free trade. Reid also produced a series of budgetary and administrative innovations that were a matter of personal pride for a man who served as Premier and Treasurer simultaneously (Reid, 1917). By the time of the Federal Conventions, government statistician Timothy Coghlan produced optimistic figures that indicated that by $1941 \mathrm{New}$ South Wales and Queensland were going to grow into the dominant colonies with populations of 8.2 and 7.5 million, while with her limited territory Victoria would inevitably fall to the back of the pack with just 4 million (Official Report of the National Australasian Convention Debates, 1897). The colony's self-confidence was thus very high.

While continuing to give priority to domestic reforms, Reid underwent a more tempered version of Parkes' transformation. Apparently convinced that Grover Cleveland's presidential victory meant that global protectionism was on the wane, Reid agreed to pursue Federation along the democratically elected convention lines proposed by John Quick. One of the main benefits of the convention model was that it took the issue away from the preoccupied parliament, but even then there was a significant delay between Reid adopting the proposals and the elections taking place (Pringle, 1979). Crucially, the Federal Conventions gave each participating colony 10 delegates regardless of population, while even the New South Wales delegation included only three members of the government and no members of the Labor Party that supported the government.

Reid would label the updated draft constitution 'as fair as could be expected' to be produced by a convention equalising the colonies, but it by no means represented the concerns and beliefs of Sydney's leading politicians (Daily Telegraph (DT), 13 May 1898). When the Assembly was asked to express its opinion on the draft constitution, it displayed great hostility by voting 59 to 4 against equal state representation in the Senate (Pringle, 1979). In June 1897, after the convention had begun its work, the government allowed an amendment to the Federal Enabling Bill providing that the referendum to approve the draft constitution would require a minimum of 80,000 'Yes' votes to succeed. Federalists considered this a great betrayal, even though the 80,000 was a compromise from an initial proposal that would have required a majority of registered electors $(139,000)$. Considering the fact that Barton had received over 100,000 votes at the delegate convention and that the decision would bind New South Wales for all time, it is difficult not to see the 80,000 minimum as a triflingly small safeguard. 


\section{The 1898 referendum}

\section{Forces}

Sydney's political culture had long seen political leagues formed to advocate for particular issues, disseminate literature and organise speakers, and the referendum campaign was no exception. While the pre-existing and professedly non-partisan Federal League had to create an offshoot called the Federal Association to fight the coming political battle, those opposed to the bill had to start from scratch. They created two competing organisations, the Anti-Convention Bill League and the Colonists' Anti-Convention Bill League.

The former was largely a parliamentary body led by Jack Want, Reid's AttorneyGeneral who resigned from the ministry to lead the 'No' campaign against a federation he thought would sacrifice his colony's independence and liberty (Finn, 1990). Want was backed by the radical Free Trader and Bulletin founder John Haynes and the rural free trade journalist Edward Millen. As a group, the radical Free Traders were strongly opposed to the convention bill on democratic grounds. Their presence helped to attract some Labor men to the league. However, one of the 'No' campaign's failings was a lack of integration with the Labor Electoral Leagues, despite their opposition to the bill. Though it was started by Free Traders, the league soon reached out to a number of Protectionists led by former premier George Dibbs who supported a radical unification model over mainstream Federation. Its manifesto declared that it stood for the defence of majority against minority rule.

The Colonists' Anti-Convention Bill League seems to have been the more conservative organisation, founded by rich businessman Thomas Kelly along with others like John Toohey, of brewery fame, most of whom thought that Federation would drive up taxation. There was some overlap between the two groups, but on the whole it hurt the 'No' campaign to split its resources unnecessarily. Barton claimed that:

the opponents of this bill—or one wing of them—consist of those who have enough and to spare of the money bags, while the other wing, or some of them, would be only too glad to share the money. (DT, 20 April 1898)

It was a 'Yes' campaign claim that since both radicals and conservatives opposed the bill, it must therefore be fairly balanced. Conscious of the weakness of division, the Daily Telegraph (3 May 1898) would push for the groups to merge but their cooperation was not secured until well into the campaign. Pringle (1979) argues that the 'No' organisations were weaker than their opponents, whose pre-existing league had built strong networks in the country districts. 
Both major parties were split on the referendum question, but the more powerful forces were arguably arranged on the 'No' side. For the Protectionists, both the former premier Dibbs and current leader William Lyne were opposed, though they were balanced out by some prominent ex-ministers like R.E. O'Connor. For the Free Traders, only convention delegate Joseph Carruthers and Dugald Thompson were prominent 'Yes' men. Most of the parliamentary party was opposed; and despite saying he would vote for the bill, Reid was practically opposed in all important respects. The other ministerial delegate, James Brunker, took some time before entering the fray but when he did he delivered an emphatic 'No'. For the first referendum Labor was united in its opposition to what it felt was a highly conservative constitution. While Labor supported the federal idea, the party was inherently suspicious of a movement that was often seen as aristocratic, both because it started as a top-down effort and because it was led by Barton, who as AttorneyGeneral had put down the Broken Hill miners' strike of 1892 (Pringle, 1979). There were also concerns that Labor's model of union-based electoral organisation, still only a few years old, would be less effective at a national level.

The real strength of the 'Yes' campaign was in the media. So many editors got caught up in the patriotic fervour that the newspapers that opposed the bill can be listed on one hand. They included the Labor-affiliated Worker, the Protectionist Star and the Sunday Times, while in the country Millen's Western Herald and Darling River Advocate was virtually a lone voice in opposition to the bill (Irving, 1999). The Daily Telegraph had initially supported Federation, but it was utterly opposed to the convention bill on both fiscal and democratic grounds. It did not help that the Federal Conventions had rejected the advice of the Telegraph's financial correspondent R.L. Nash, much to the chagrin of editor Lachlan Brient (Pringle, 1979). It says much about Sydney's political culture that both of its major newspapers were expressly pro-free trade, but the Sydney Morning Herald was more willing to overlook the threat Federation posed to its economic ideology. While it was no more biased than its opposition, the Telegraph employed all sorts of innovative techniques to win over readers. These included bold headlines, short propaganda articles reproduced in multiple issues, and a special edition printed to reach every elector in the colony.

\section{Arguments}

Without doubt the two largest issues of the campaign were the limitations the bill placed on majority rule and the financial provisions. It was only in 1893 that plural voting had been abolished in New South Wales and a Senate that gave equal representation to states regardless of population threatened to overturn decades of reform that had finally secured equal voting strength for every man. As it stood, there would be 12 senators representing 2,500,000 people and 18 representing 500,000 (Evening News, 4 April 1898). The proponents of the bill argued that Federation would only be possible with equal representation because otherwise the small states 
would refuse to join. This was countered by those that suggested the small states had a financial imperative to federate, and pointed to Germany, Canada and Switzerland for examples of federations where the constituent provinces were not entitled to equal representation. There was even a suggestion that the three largest colonies should federate on a more democratic basis and then the smaller colonies could join if they so wished (DT, 22 April 1898).

It was clear that the Senate was modelled on the US Constitution, and this was controversial in itself. The Telegraph (6 April 1898) quoted Walter Bagehot on the American Senate having 'no self-evidence' and being the product of circumstance; there was no need for a Senate provided the federal government's powers were limited and it was only deciding on issues that were truly national. The United States was the exception rather than the rule and given that the country had quite recently endured a bloody civil war over states' rights it was hardly a model exception. James Bryce was quoted to show that the Senate had always been the bulwark of slavery, and its very presence fed into the states' rights narrative. From the opposite perspective, the civil war was also used as an argument against the indissoluble union. Once New South Wales voted 'Yes', the only way out would be through unimaginable violence.

There were many 'No' advocates who could accept a Senate with equal representation, provided they secured several defences of majority rule. The first had to do with money bills. Westminster tradition had long accepted that the popular House should have control over taxation and appropriation, and since taxes were to be collected per capita rather than per state, democrats argued that those providing the money needed to have control over how it was spent. The constitution accepted this proposition by declaring that only the House of Representatives could initiate and amend money bills, but the Senate was left with the power to block money bills and suggest amendments. The 'No' side argued that the power to block would be as good as the power to initiate or amend because the Senate could create a stalemate until the government was forced to back down and its members were secure, because only half faced election at a time. This threatened to undermine the principles of responsible government, because a ministry might very well need a majority in both Houses just to ensure that public servants were paid. It also opened the door for Brunker and others to cry 'no taxation without representation' (Sunday Times (ST), 29 May 1898).

In order to overcome a situation where the Senate acted obstinately, it had been New South Wales delegates who introduced a deadlock provision allowing for a double dissolution and then a joint sitting where a three-fifths majority would succeed (Quick \& Garran, 1901). While, with Queensland absent from the Federal Conventions, New South Wales and Victorian representatives would have three-fifths against the three smaller states, this provision still gave far too much weight to the 
smaller states, particularly with the constitutional minimum of five members of the House of Representatives. It was also pointed out that the deadlock mechanism was far too slow to deal with the pressing consequences of a deadlock over money bills.

Labor thought that its platform plank of 'initiative and referendum' could overcome some of these limitations by taking questions directly to the people (Nairn, 1973), but without Labor delegates the convention had not adopted this. Instead they introduced a referendum mechanism for constitutional change that was quite rigid and went completely against the evolutionary nature of the much-lauded and unwritten British Constitution. Not only did the referendum require a majority in a majority of states, again seen as undemocratic, but the $1898 \mathrm{draft}$ required that a referendum proposal would have to pass both Houses. There truly was no getting past an obstructionist Senate.

New South Wales had long feared joining a Federation because her sister colonies all employed protectionist tariffs to some extent. It was therefore highly controversial when the 'Braddon blot' seemed to decide the fiscal issue before a federal parliament even sat. The fundamental problem, which has continued to poison Federation ever since its inception, is the entanglement of federal and state finances. Nationhood and intercolonial free trade required that the federal government take over customs, but every state except New South Wales relied on tariff revenue to avert bankruptcy. The solution proposed by Tasmanian delegate Edward Braddon was to give threequarters of all customs revenue back to the states. This seemed to guarantee a high tariff, and in the convention it was opposed by most of the New South Wales delegates, including Barton (Quick \& Garran, 1901).

Two of the major arguments against it were that it would require the federal government to levy four times the amount of taxation required by its expenditure, and that it seemed to imply that the federal government would have to look after the financial interests of the states. Once the latter principle was accepted it opened the door to calculations on how high tariffs would have to be to keep the states solvent once the services given over to the federal government were factored in (DT, 27 May 1898). Different states had different financial needs, but the argument went that the tariff would either have to be set to a level that would accommodate the most 'necessitous State' (DT, 31 May 1898), which was Tasmania, or that the tariff would be set according to the average state and the more needy would have to be bailed out in some other fashion. No matter what, it was clear that New South Wales would have to deal with a vast increase in customs taxation that might jeopardise her prosperity.

New South Wales would theoretically get this money back in the form of the threequarters, though this was only guaranteed during the 'booking keeping period' of the first five years. After that it appeared that the federal government could allocate it to any state and given the financial needs of others it seemed that a form of horizontal 
fiscal equalisation was inevitable. The idea of New South Wales bankrolling her sisters was easy to attack, but even if she got back her three-quarters there were other problems. The money could not simply be given back to those who paid it, but would have to be spent. Many feared that the money would see a large increase in wasteful government spending. The money could be used to abolish other taxes, but the idea of getting rid of Reid's land and income taxes and funding government through burdens that fell on the masses would be an utter betrayal of the working class and everything the premier stood for. Reid himself replied to the idea with 'what have I been fighting for with others for four years?', a line that would be quoted against him at the next referendum (DT, 9 June 1899). Carruthers, who at first tried to ignore political reality by arguing that Braddon would force federal governments to avoid tariffs because they only received one-quarter of the revenue, came up with the idea of using the money to subsidise railway fares. The Telegraph (25 May 1898) had a field day with this, reporting

as a sincere politician, it consequently devolves upon $\mathrm{Mr}$ Carruthers to propose the immediate abolition of free trade in New South Wales, with the view of putting a customs tax calculated to yield more than a million pounds over the requirements of government, in order that we may be provided with the boon of cheap fares to Hurstville and other suburbs [which happened to lie in his electorate of St George].

To compensate for the loss of overall free trade, 'Yes' pointed out that New South Wales would have guaranteed intercolonial free trade; 'No' argued that this was a hollow gift (DT, 17 May 1898). The colony did vastly more trade with the rest of the world than it did with her sisters, relied on excess import ships to keep exports competitive, and the main colony she did trade with, Queensland, was not even going to be in the Federation at this stage (Kemp, 2019). 'No' also maintained that intercolonial free trade was undermined by the bounties provision, which ensured that any 'grant or agreement' made before 30 June 1898 would have to be paid out by the federal government. Victoria subsidised a number of products including beet-sugar, wine and coal, and the fact that the Commonwealth would pay for this allowed 'No' to argue that the New South Wales taxpayer would foot the bill for an attack on themselves (DT, 2 June 1989). Since the clause guaranteed 'agreements' made before 30 June, the 3 June referendum date allowed 'No' to run a scare campaign that Victoria would enter into a series of agreements after the referendum and leave the federal government to foot the bill (DT, 10 May 1898).

One of the 'No' campaign's most difficult tasks was to combat the emotional power of the 'Yes' campaign's appeal to nationalism. Most insisted that they were for Federation but opposed to the 'lawyers' bill' as it currently stood. Their argument was that 'No' would not mean an end to Federation, but an improved Federation thanks to New South Wales exercising her bargaining power. She was going to provide as much as 45 per cent of the money, so the other colonies would be forced to wait for her. A.B. Piddington told the Women's Suffrage League that 'New South 
Wales was mistress of the situation; the key to federation hung at her girdle, and there could be no federation without her' (DT, 21 April 1898). Frequently, 'No' appealed to people to be guided by their heads not their hearts, imploring 'men of all classes and political creeds, who are not to be led into disregard of menacing actualities by any amount of oratorical vaporing concerning splendid possibilities of the future' (DT, 5 April 1898). At the end of the campaign the Telegraph (2 June 1898) vented its frustration:

The Conventionist poet who claimed a lien on the Southern Cross will have to forego his celestial mortgage, and the fact that this is a 'sunny land' will be quietly relegated to the oratorical dust-heap.

Despite the pressure to maintain an overall pro-federal position, there were those who fought the 'No' campaign as a defence of local sovereignty. Want was one of the brasher speakers on this front, telling a Marrickville audience 'if love of country and a desire for the welfare of its inhabitants were provincialism, then he would proudly be regarded as one, and was content to bear the name' (DT, 1 June 1898). Legislative councillor Louis Heydon argued that 'Yes' were underestimating the size of New South Wales, which was bigger than any of the great nations of Europe and could house over 50 million people by the year 2000 (DT, 11 April 1898). Even in an ideal federation, New South Wales would have less control over her affairs than she had previously; this is why it was so important that on paper the constitution seemed to give only limited powers to the federal government. It was one of the few things that Reid fully approved of (McMinn, 1989). The issue would have no doubt been far greater had the electors known how things would pan out.

\section{Key moments}

Coming right at the beginning of the campaign, Reid's 'Yes-No' speech was certainly a defining moment, but it was not necessarily the telling factor that betrayed federalists like Wise would have us believe. Given reasons of space, it is probably not worth dwelling too long on the one aspect of the referendum campaigns that has received detailed attention. With his trademark oratorical skill, Reid made a series of cutting critiques of the draft constitution before concluding almost glumly that he was still going to vote for it. His criticisms focused on the relationship between the two Houses and the effects of the Braddon blot, as well as the sleeper issues of New South Wales possibly losing control over her rivers and the failure to set the site of the federal capital in New South Wales.

It may be tempting to engage in speculation over how the referendum would have gone without 'Yes-No', but it is difficult to imagine Reid not doing what he did. As has been argued, the convention bill cut against almost everything he stood for. It is often forgotten that even the lukewarm support 'Yes-No' gave Federation provoked such a backlash that Reid had to cancel a proposed sitting of parliament 
because he was likely to be defeated in the Legislative Assembly. The Telegraph (1 April 1898) treated the move as an 'act of constitutional violence'. Free Trade backbencher James Ashton said an earthquake would have surprised him less than the prorogation. Perhaps responding to this pressure, throughout the campaign Reid became ever more critical of the bill to the point where 'Yes' completely scorned him. L.F. Crisp (1990, p. 16) has argued that Reid's 'speeches provided the bullets which other people fired for the purpose of killing' the bill. To a large proportion of his free trade and working-class supporters, Reid's most inexplicable betrayal was not 'Yes-No', but the fact that he turned from this position into such a resolute supporter of the 'Yes' campaign after securing a number of concessions that never really solved the fundamental problems that he identified.

A twist that had equal impact on the campaign was the sudden politicisation of Coghlan the government statistician. Appointed to his position at a young age, Coghlan had been something of a prodigy, producing a guide to the 'seven Colonies of Australasia', a triumphant book on the Wealth and Progress of N.S.W., and an innovative statistical register (Knight, 1961). Coghlan's famed reputation had seen him asked to provide key advice to the finance committee of the Federal Conventions, and he would later be offered the position of federal government statistician (Hicks, 1981). The finance committee's conclusions had tended to favour the figures provided by strong pro-federalist Edward Pulsford, who naturally thought Federation would cost less than the sober bureaucrat had argued (DT, 6 April 1898). In the heat of the campaign Barton callously tried to pick holes in the figures Coghlan had offered the convention in order to downplay as much as possible the costs of Federation. This prompted Coghlan to come out in public and defend his reputation, arguing that if anything the figures he offered were conservative and underestimated the amount that would need to be spent on defence (DT, 22 April 1898). The whole issue blew up into a wide-ranging debate over both the costs of the federal government and the tariff that would be required under the conditions of the Braddon blot.

Eventually a combination of Free Trade MPs such as Want and Sydney Smith, along with the Colonists' League, convinced Reid to launch an inquiry into these financial issues. The three-person committee was chaired by the neutral manager of the Bank of New South Wales, John French, with Bruce Smith representing the 'Yes' side and Dr MacLaurin representing the 'No' side. It eventually produced a report that suggested the direct costs of Federation would be somewhat contained but that the tariff itself might be up to a million pounds higher than predicted by Pulsford and vastly higher than Barton's gross underestimation (DT, 1 April 1898). Both sides claimed vindication, but the focus on costs undoubtedly played into the 'No' campaign's hands. The 'Yes' campaign used the report to claim that Federation would only cost $3 \mathrm{~s} 6 \mathrm{~d}$ per person, or as Wise famously put it, little more than registering a dog (Crisp, 1990). This figure was, however, based only on the immediate costs of 
the federal government after factoring in transferred services, and did not account for the increased tariff that could not be given back to the people who paid it. Once that was factored in, the report suggested that the cost would be 22s 6d, which 'No' was then able to depict as an absolute minimum while also highlighting the fact that everyone's calculations had also included a doubling of postage rates.

\section{Results and assessment}

The colony-wide result saw 71,595 'Yes' votes to 66,228 ' $N o$ ', thus failing to reach the 80,000 number. Dibbs pointed out that Barton had lost tens of thousands of votes since the delegate elections and called for him to resign as head of the federal movement (ST, 5 June 1898). Overall there was a noticeably low turnout, which some blamed on the fact that, unlike in the delegate elections, electors were only allowed to vote in their electorate. The election was on a Friday and was declared a public holiday, so others suggested that people had gone away on vacation rather than voting. The Telegraph (4 April 1898) argued that a significant number of 'No' voters took advantage of the 80,000 minimum, which meant anyone who did not vote was essentially helping 'No'. If this was the case then it was a problem the paper had helped to produce; 'No' voters probably read the Telegraph whose writers seemed so assured of victory that they hardly drummed up an incentive to vote.

In Sydney, the city saw a majority of 677 for 'No', and the suburbs 2,961, making a total of 3,638 (DT, 21 June 1899). ${ }^{4}$ The fact that the 'No' arguments had cut through can clearly be seen in the Sydney Morning Herald (2 June 1898), whose last-minute pitch to voters the day before the referendum spent a good deal of time refuting 'No' before providing any reason to vote 'Yes'. They began almost comically by pointing out that Reid was voting 'Yes' before suggesting that the constitution was amendable, the joint sitting ensured majority rule, and that it would only cost $3 \mathrm{~s} 6 \mathrm{~d}$ per person. Only then did they get to nationalistic catchphrases like 'federation will build up a national Australian spirit', 'union is strength' and 'vote for a 'White Australia'. A number of MPs found that their electorates had voted against their wishes. One of the most notable was Carruthers, whose safe Free Trade seat of St George registered a 'No' majority of 435 from 1,789 votes, the 1,112 'No' voters being the most of any electorate (Sydney Morning Herald (SMH), 4 June 1898). Three electorates had more than 1,000 'Nos', while the top 'Yes' vote was 860 in South Balmain. Reid's electorate polled a 'Yes' majority of 126.

4 Including Canterbury which the SMH classified as part of Sydney but the DT did not. 


\section{The secret Premiers' Conference}

When the results came in, many disappointed 'Yes' campaigners wanted to amend the enabling bill to retrospectively remove the 80,000 minimum. This was soon dropped as it was politically untenable compared to Reid's tactic of seeking concessions to make the draft constitution more acceptable to New South Wales (Quick \& Garran, 1901). Reid approached the other premiers about this but, thanks in part to the secret lobbying of Barton, they refused to meet with him until after the election, which was due shortly (Hirst, 2000). That election saw a transformation of the major parties. The Protectionists replaced Lyne with Barton, agreed to temporarily drop the fiscal issue, and renamed themselves the 'National Federalists'. Reid oversaw a similar transformation, labelling the Free Traders the 'Liberal and Federal Party' and trying to differentiate from his opponents on the basis of seeking greater concessions than the more compromising Barton. A small majority in a lowturnout referendum had, remarkably, convinced both fiscal parties to compromise their identities in order to chase votes.

The election results saw Reid hold on with Labor support despite losing several seats. Since both parties were projecting themselves as Federation parties it is virtually impossible to explain what the results reflected. Clearly people who voted 'No' would have an incentive to back Reid as the less ardent federalist, but Protectionists would have found this a hard pill to swallow. ${ }^{5}$ Notably, Labor gained as many seats as it lost, so the firmer 'No' stance did not appear to be an electoral handicap. Several ardently federalist Free Traders sought seats as members of Barton's party, but most were unsuccessful (Loveday et al., 1977). As this was also the first election since the introduction of Reid's land and income taxes, a backlash among the wealthier classes seems to have cut through the other issues. ${ }^{6}$ What is plain is that all the clarity Reid's free trade agenda had provided New South Wales politics with had evaporated.

After the election, Reid had a series of suggested amendments to the draft constitution approved by parliament and then took them to a conference with the other premiers, including Queensland. The concessions secured were that the capital site be in New South Wales but at least 100 miles from Sydney, an absolute majority could succeed in joint sittings, the Braddon clause was limited to 10 years, state boundaries could not be altered without the consent of the people of the state and referendums only required the approval of one House of Parliament. Requests to remove the 'reasonable' limitation in the rivers clause or further limit the Senate's power over money bills were rebuffed.

5 Pringle (1979) argues that Protectionists hated Reid more than they hated the bill.

6 Hirst (2000) suggests the taxes were the main reason Reid lost seats. 
Reid then introduced an enabling bill for a new referendum, this time skewed in favour of 'Yes' through the lack of a minimum vote and the ability of electors to vote in any electorate, the latter increasing the possibility of voter fraud. It remained a matter of fierce contention. The Legislative Council had to be swamped with new members in order to pass the enabling bill, while the Labor Party had to endure an internal debate over whether to vote for the enabling bill despite what were considered to be inadequate changes to the draft constitution (Nairn, 1973). Labor concluded that it was resolutely opposed to the updated bill, but James McGowen successfully maintained that the issue should be put to the people.

\section{The 1899 referendum}

\section{Forces}

Organisationally, there was little difference between the referendum of 1899 and its predecessor. Both the Anti-Convention Bill League and the Colonists' League had maintained their operations, and despite the previous year's efforts to secure cooperation they remained separate entities. Jack Want had resigned his leadership of the Anti-Convention Bill League in order to retake his position in the Reid Ministry and was replaced by Dibbs. The real change was in the position of the parliamentary parties. In the election, Reid had made Federation a party issue and he was therefore able to call on members to fall into line at the behest of party solidarity. In 1898, this would have been impossible, even if Reid had tried, but the referendum result and Reid's subsequent ownership of the negotiations had shifted the circumstances. The Free Traders had once had a considerable problem with party discipline, but Reid and Carruthers had gone to great lengths to instil a more unified culture and they were now far ahead of the Protectionists in this area (Gorman, 2018). The addition of Reid gave 'Yes' the colony's best platform speaker. Demonstrating his trademark political savvy, he turned the screws on his opponents by pointing out their contradictory positions. MacLaurin and the Telegraph (16 June 1899) supported a stronger form of Federation than that of the convention bill, so Reid was able to paint himself as the champion of New South Wales autonomy by contrast. Want remained strongly opposed to the Federation bill, but he took an ill-timed trip to Egypt and his only real contribution to the campaign would be via telegram.

Having adopted Barton as their leader, the Protectionists were somewhat restrained, although many of those who had opposed the bill last time were out in force again. The most intriguing figure was Lyne. He at first stayed silent, perhaps in the interests of his party, but after the Telegraph called him out on his absence, he led a vigorous late charge for the 'No' campaign. It seems that at first he thought the success of 'Yes' was a forgone conclusion, but as opposition stiffened he may have hoped that 
a 'No' result could have propelled him back to the leadership of the opposition and even the premiership. Labor took a far more active role in the 'No' campaign this time around, led by Billy Hughes and William Holman, who had both tried to stop their party supporting the enabling bill (Nairn, 1973). Many of the most devastating critiques were given by Labor men as champions of democracy, but William John Ferguson and Richard Sleath, two members from far western electorates concerned about the safety of their seats, decided to break with caucus discipline and campaign for 'Yes', leading to their expulsion.

The only newspaper to change its position was the Star, which fell in line behind Barton's leadership. The Telegraph seemed to thrive on the fact that it was taking on the world, and if anything its writers fought a more spirited campaign than the last time. They took great delight in quoting the previous constitutional criticisms of Reid and other backsliders against their current positions, even doing the same with extracts of Barton debating contentious clauses during the Federal Conventions. They made it into a regular section called 'in the witness box', where the politicians were effectively cross-examined by themselves. The paper dubbed the updated constitution the 'Secret Conference Bill' and regularly drew out the fact that one of Reid's main attacks on the 1891 bill was that it was drafted behind closed doors (Pringle, 1975). They also seized on Barton justifying his support for both versions of the bill by claiming it was substantially the same, reprinting this quote in multiple editions to undermine Reid's claim to have improved it.

A new strength of the 'Yes' campaign was the endorsement of a number of influential churchmen (Pringle, 1975). While the churches as institutions avoided giving an official position, individual clergy were given a free rein to express their opinion.

Though they had already been heard in the first campaign, women were even more vocal in 1899 on both the 'Yes' and 'No' sides. A Miss Hickman told a meeting of 200 women under the auspices of the Colonists' League that 'women felt most keenly the defect in the Constitution which prevented them from recording their opinions at the ballot-box'. Nevertheless, 'the opinions expressed by thinking women in public meetings would have due weight with all thinking men' (DT, 9 June 1899). They tended to argue from a democratic point of view and were quite wary of a parliament that would sit so far away from its people. Referring to Wise's quip on the costs of Federation, feminist Belle Golding pointed out that a mongrel dog could be put down but they would be stuck with a flawed Federation for all time.

\section{Arguments}

The 1899 referendum was if anything fought more fiercely than its predecessor, but since many of the arguments were simply a replay of 1898 there is little point repeating them. The new dimension was the debate as to whether Reid's amendments fixed the problems onto which the referendum campaign had shone 
a light. 'No' maintained that they absolutely did not and that in some cases they had made things worse. Starting with the capital site, the 100-mile limit was considered an attack on Sydney, which now knew for certain that it would not be the national capital. MacLaurin asked:

what has Sydney done to Mr. Reid that he should seek to affix such a stigma to a city which, most people think, has treated him with the greatest consideration and kindness? (DT, 16 February 1899)

The Telegraph (7 May 1899) produced a detailed map demonstrating the 100mile radius, and showing how it covered from Newcastle to Nowra and crossed through Bathurst. When it was left up to parliament, there was some hope that Queensland could have helped secure the honour for Australia's first city, but now that was out the window. Instead, not only was there the 100-mile limit but also a guarantee that parliament would sit in Melbourne in the meantime. This meant that the city would have all the financial benefits of government departments, its politicians would have an easier time attending parliament and that its Protectionist newspapers would dominate the press gallery. Moreover, there was not even a mechanism that would force the capital to move on from Melbourne by a certain date; theoretically, it could be there for a century if no other capital site had been settled upon (DT, 22 April 1899).

On the issue of the financial clauses, Reid's failure was almost self-evident. The 10year limitation on the Braddon blot was little more than an evasion, too far in the distance to detract from the problems Reid himself had identified with the clause. Worse still, the price of the time limit was the introduction of section 96, which allowed the Commonwealth to make grants to the states 'with attached conditions'. This was attacked as proof that New South Wales was expected to dig into her pockets to bail out the other states' financial needs. Reid found himself in the awkward position of having to downplay his strong criticisms of the previous year. Having committed to not removing his land and income taxes, the premier proposed using the three-quarters surplus on farm subsidies and pensions, a populist move the Telegraph (10 May 1899) took as further proof of the wastefulness of Federation. It said he wanted people 'taxed for their own good' like a typical Protectionist.

Because Braddon remained, all the financial debates of the last year were largely repeated, though the nature of the repetition meant that people were less engaged, at significant damage to 'No'. To enliven the debate, 'No' turned to attacking the idea that Australia would be grossly over-governed by its seven parliaments and that Federation would add needlessly to the overall costs of government. Lyne added together all of Australia's MPs to get 750 and suggested that if Westminster had the same level of representation it would have to seat 8,000 (DT, 3 June 1899). 
If the finances were just as bad, the central question became: was the bill any more democratic? 'Yes' had two amendments to point to. The first was that referendums would only require the support of one House to get off the ground. This was easy to dismiss as the 'double majority' would ensure that any referendum question that cut against the interests of the smaller states would be defeated anyway. The focus thus turned to the absolute majority. At first even 'No' seemed to concede that this was a slight improvement, but later there were attacks on the fact that an absolute majority, similar to the 80,000 minimum, would take an absence as a 'No' vote. Considering that this was an era when MP absences were high and the distances involved in a federal parliament would likely exacerbate this, many feared that the absolute majority would often be unachievable. Hughes argued that 'the difference between a three-fifths majority and an absolute majority was much the same as that between one ton of coal and two tons falling on your head' (DT, 31 March 1899). Holman went to great lengths to explain the procedure of a double dissolution and demonstrate that the absolute majority had done nothing to overcome the fact that the deadlock provisions could not be used in money bill situations (ST, 21 May 1899). The Senate still had a right of veto over the government, as 1975 would show.

The amendment to protect state boundaries took away a scare campaign on the annexation of the Riverina and other areas, but this was a clause that benefited all states, so it was hardly a concession to New South Wales. Lyne argued that the other premiers had run rings around Reid and that at the very least he could have secured the capital without equivocation (ST, 12 February 1899). To his opponents, Reid had completely failed in his attempt to haggle and the fact that he tried to save face by pretending otherwise was the source of much scorn. Those expecting the premier to repeat his nuanced stance of 1898 felt betrayed by his partisanship: towards the end of the campaign he was burned in effigy outside the Glengarry Castle Hotel in Darlington as the 'strangler of majority rule' (DT, 13 June 1899).

More and more, the 'No' campaign tried to counter the emotional appeal of 'Yes' with their own appeal to the people to protect their rights and those of their children. A mass meeting of the Political Labor League was told that equality at the ballot box had been the central goal of democratic reform since the Chartist movement (DT, 14 June 1899). McGowen explained to a meeting at Newtown that:

to accept the present bill would be not only to diminish their own privileges, but to destroy the rights and liberties of future generations; and on these grounds he appealed to the working men of New South Wales to show that they understood their own interests, and were determined to pass as a heritage to their children the freedom now enjoyed, by voting against the bill. (DT, 5 June 1899)

The appeal to emotion was part of a more concerted effort to undermine the 'Yes' arguments in favour of Federation. Holman led a critique of the military necessity of Federation, pointing out that Australia would still be reliant on the Royal Navy 
and that Tasmania was hardly going to bolster New South Wales' military divisions in any meaningful way (DT, 16 June 1899). It was also pointed out that the only way that defence would improve through Federation was if there was an increase in spending, but the 'Yes' campaign had been adamant this would not be the case. Though for the most part it stayed away from issues of race, while 'Yes' claimed to be the champions of 'white Australia', in its desperate last push 'No' made some opportunistic and unfortunate use of racial bogies. These included that Federation with Queensland might flood the rest of Australia with the Pacific islanders of the sugar-cane farms and also that the federal government's takeover and development of the Northern Territory would not only mean unnecessary expenditure but also the use of labourers more suited to tropical climates.

\section{Key moments}

The most controversial moment of the 1899 campaign was the Public Service Board's decision to issue an edict prohibiting public servants from participating in the Federation debate. The Sunday Times (1 June 1899) described this as an 'un-British' and sinister import from the United States. The Telegraph denounced the attack on free speech where,

more than a tenth of the electors of the colony have the iron hand of bossism clapped across their mouths, so that while the Premier and his new allies go about deluding the people not one of them may utter a word. (12 May 1899)

While the prohibition applied to all public servants, it was clearly directed against Coghlan. As one of the most senior public servants, Coghlan was actually a commissioner of the supposedly independent board but he caved in to political pressure in not opposing the prohibition. The Telegraph led a campaign repeatedly criticising the 'muzzling' of Coghlan while speakers like Lyne often brought up the issue. A defensive Reid insisted that Coghlan was available to offer his expert advice to both 'Yes' and 'No' MPs in private, but the premier refused to back down in the face of mounting pressure.

Things got worse when the government allowed Major-General French to deliver a pro-Federation appeal, demonstrating selective enforcement in favour of the 'Yes' campaign (DT, 14 June 1899). The depoliticising of public servants was made all the more perverse when 'Yes' tried to deliberately court their votes, making speeches claiming that Federation would create new job opportunities or increase wages. Barton suggested that a legislature made up of ex-ministers would be more appreciative of public servants and ironically tried to woo them with the fact that federal employees would be freed from the strictures of Reid's Public Service Board (DT, 15 May 1899). 'No' countered with the claim that public servants in transferred departments would have to reapply for their jobs, many of which might be relocated 
to Melbourne as the temporary capital. It was also pointed out that Victoria paid her public servants less, and that in the push for economy that even 'Yes' was advocating the lower pay rates were likely to become the standard (1 June 1899).

Despite the negative press, Reid's decision successfully undermined the 'No' campaign to a significant extent. The Telegraph tried reprinting Coghlan's statements from the previous year with the headline "when the "muzzle" was off', but because his calculations had not included Queensland they were out of date and ineffective. Dr MacLaurin did his best to pick up the slack, delivering a series of devastating speeches on the costs of Federation. However, the fact that he was both a known partisan and a member of a Legislative Council, which was associated with hard-line conservatism, meant that his views were less likely to be heeded by disinterested voters.

The other key moment was when Queensland passed an enabling bill ensuring that it was going to hold a referendum on Federation (Quick \& Garran, 1901). Reid had long courted Queensland, believing that their shared regional interests would be an important counterbalance to the southern states. As a 'medium'-sized colony and as one presumed to have great potential for growth, her absence was sorely missed during the small state victories of the Federal Conventions. The parliamentary debate on the enabling bill was going on simultaneously with the referendum, and its outcome was a great boon to 'Yes'.

\section{Results, assessment and conclusion}

The result of the 1899 referendum was 107,420 'Yes' and 82,741 'No'. There had been a large increase in voter turnout, which was due to a number of causes. First, the voting regulations that allowed electors to vote outside of their electorate. Second, the increased effectiveness of both the 'Yes' and 'No' organisations and the fact that people inclined towards 'No' could no longer rely on the 80,000 minimum. Finally, there was the sense that the Federation issue was coming to a head. The Telegraph and other 'No' campaigners tried to insist that an adverse vote would not mean the end of Federation but the possibility of a Federation on better terms. This was effective in 1898, but with a second round of negotiations having now occurred, it was clear that a vote of 'No' would set back Federation for at least a decade. It had essentially become an issue of take it or leave it.

The Sydney vote saw a majority of 479 'Yes' in the city and 843 'No' in the suburbs, making a slim 364 margin against overall (DT, 21 June 1899). The ability to vote in any electorate seems to have had the biggest impact in the city, where several electorates had voter turnouts well above the numbers registered on their electoral rolls. The Telegraph (21 June 1899) suggested that if a significant proportion of

7 Including Canterbury, which the SMH classified as part of Sydney but the DT did not. 
these extra voters represented people travelling from the country districts, who were statistically more likely to vote 'Yes', the majority for 'Yes' in these electorates may not be an accurate guide to local feeling.

While there had been a noticeable swing to 'Yes', the fact that Sydney registered another 'No' majority is simply remarkable. Virtually everything was stacked against 'No', which had to face off against the government, the opposition, the majority of the press, churchmen, the levers of government like the Public Service Board and the momentum of Federation. In the 'No' corner was an incongruent assortment of unpopular Legislative Councillors, contrarian Protectionists and the Labor Party. Considering the unpopularity of the first two groups in the city of Sydney as demonstrated by the 1895 election result, almost all of the burden of prosecuting the 'No' case fell to Labor and the Telegraph. It must be remembered that Labor was still very much a junior party compared to the Free Traders, who had a virtual stranglehold on the city's middle-class voters. ${ }^{8}$ The results showed that a significant proportion of these voters rebelled against the dictates of the Free Trade Party, and instead voted for what was sold as democracy, lower taxation and inexpensive government. These issues were the ones that had won Reid the 1894 and 1895 elections, and they dominated the debate in both referendums.

Those free trade supporters who voted against Federation were to have their fears confirmed. The federal parliament did raise large tariffs, first for revenue then in the name of protection. The Braddon clause, combined with an economic downturn, did lead to a large rise in New South Wales government spending, which even the fiscally conservative governments of Carruthers and Charles Wade were unable to fully reverse (Gorman, 2018). Carruthers himself came to personify the frustrations of the free trade-sympathising people of New South Wales with Federation, threatening secession just a few years into the new arrangement. The concerns about democracy remain a matter of perspective. The representatives of the smaller states have tended to vote along party rather than state lines, but this does nothing to diminish the fact that the strength of a Tasmanian elector's Senate vote is far greater than that of someone from New South Wales.

Reid's domestic legislative agenda thus did not survive Federation. Ardent Federationists like Wise and Deakin went to great lengths to paint Reid as the villain, but given the perilous political situation he had to navigate he should arguably be their hero. In contrast to the traditional story, Reid's real sacrifice was of the interests of the people who had supported him the longest. He would lose the premiership in September 1899 in large part because he had alienated both sides of the Federation question. In many respects Reid secured Federation 'at any price'.

8 Labor only bothered to run candidates in 12 of what Nairn (1973) identifies as 40 Sydney seats in 1898. 


\section{References}

Coghlan, T.A. (1898). Statistics of the seven colonies of Australasia 1861 to 1897. Government Printer.

Crisp, L.F. (1990). Federation fathers. Melbourne University Press.

Finn, P. (1990). Want, John Henry (1846-1905). In Australian Dictionary of Biography (Volume 12). Melbourne University Press.

Gorman, Z. (2016). A contested contest: George Reid's election to the leadership of the New South Wales free trade party. Journal of Australian Colonial History, 18, 182-197.

Gorman, Z. (2018). Sir Joseph Carruthers: Founder of the New South Wales Liberal Party. Connor Court.

Green, A. (2007). New South Wales election results 1856-2007. Parliament of New South Wales.

Hicks, N. (1981). Coghlan, Sir Timothy Augustine (1855-1926). In Australian Dictionary of Biography (Volume 8). Melbourne University Press.

Hirst, J. (2000). The sentimental nation: The making of the Australian Commonwealth. Oxford University Press Australia.

Irving, H. (1999). The centenary companion to Australian Federation. Cambridge University Press.

Kemp, D. (2019). A free country: Australia's search for Utopia 1861-1901. The Miegunyah Press.

Knight, K. (1961). Patronage and the 1984 Royal Commission of Inquiry into the New South Wales Public Service. Australian Journal of Politics and History, 7(2), 166-185.

La Nauze, J.A. (1972). The making of the Australian Constitution. Melbourne University Press.

Loveday, P., Martin, A.W. \& Weller, P. (1977). The emergence of the Australian party system. Hale \& Iremonger.

Martin, A.W. (1980). Henry Parkes: A biography. Melbourne University Press.

McMinn, W.G. (1989). George Reid. Melbourne University Press.

Nairn, B. (1973). Civilising capitalism: The Labor movement in New South Wales 1870-1900. Australian National University Press.

Official Report of the National Australasian Convention Debates. (1897). First Session. Adelaide. C.E. Bristow, Government Printer.

Persse, M. (1967). Wentworth, William Charles (1790-1872). In Australian Dictionary of Biography (Volume 2). Melbourne University Press. 
Pringle, R. (1975). The Federation issue in New South Wales politics 1891-99. Australian Journal of Politics and History, 21(2), 1-12.

Pringle, R. (1979). Public opinion in the Federal Referendum campaigns in New South Wales 1898-99. Journal of the Royal Australian Historical Society, 64, 235-251.

Quick, J. \& Garran, R. (1901). The annotated Constitution of the Australian Commonwealth. Angus \& Robertson.

Reid, G. (1917). My reminiscences. Cassell \& Co. Ltd.

Wise, B. (1913). The making of the Australian Commonwealth, 1889-1900. Longman, Green \& Co. 
This text is taken from Agenda, Volume 27 - Number 1, 2020, edited by William Coleman, published 2020 by ANU Press, The Australian National University, Canberra, Australia.

doi.org/10.22459/AG.27.01.2020.06 